\title{
Evaluating the Development Degree of Qazvin Province Counties Using the Factor and Cluster Analysis
}

\author{
Fatemeh Shahriar $^{1}$, Mehdi Momeni ${ }^{1}$, Majid Montazeri ${ }^{2}$ \& Alireza Freidooni ${ }^{3}$ \\ ${ }^{1}$ Faculty of Humanities, Najafabad Branch, Islamic Azad University, Najafabad, Isfahan, Iran \\ ${ }^{2}$ Assistant Professor of Climatology, University of Isfahan, Isfahan, Iran \\ ${ }^{3}$ Faculty of Management and Accounting, Qazvin Branch, Islamic Azad University, Qazvin, Iran \\ Correspondence: Fatemeh Shahriar, Faculty of Humanities, Najafabad Branch, Islamic Azad University, \\ Najafabad, Isfahan, Iran. E-mail: af_shahryar@yahoo.com
}

Received: September 23, 2014 Accepted: October 11, $2014 \quad$ Online Published: December 2, 2014

doi:10.5539/ass.v11n1p130

URL: http://dx.doi.org/10.5539/ass.v11n1p130

\begin{abstract}
Regional planning results from spatial development and economic planning in order to construct a co-ordinate and balanced construction in the regions and districts and to reduce regional imbalances by three elements of space, activity and human. Hence, it is crucial to realize the regional discrepancies and to understand their potential and weaknesses and to distinguish regional imbalances to establish a comprehensive socio-economic plan in the region. By employing quantitative methods and criteria for classification, the researcher intends to recognize, decrease and eliminate the existing inequalities. The current paper is going to specify the development degree of the counties of Qazvin province using the descriptive analysis approach. The researcher has used 48 development indices in population, infrastructure, economic- social, cultural and hygienic fields which have been extracted from statistical annals of 2011. The researcher has applied the main elements on the correlative coefficient of the data, and then employed SPSS to analyze these indices and classified them into four meaningful and significant categories which contain 100\% data processing. The results show that Qazvin is the most developed county and Takestan, Bouein Zahra, Abyek and Alborz have respectively been ranked from second to fifth counties which are benefited from development factors. Then, regarding the development level, the researcher has used cluster analysis approach and classified the above mentioned counties in three equal groups. Qazvin has been the most developed and is placed in the first group, and then Takestan and Bouein Zahra have been classified in the second group (nearly developed) after that Abyek and Alborz are the least developed and have been placed in the third group for which cluster dendogram has been drawn.
\end{abstract}

Keywords: development degree, factor analysis, cluster analysis, Qazvin province

\section{Introduction}

The human inclination to achieve a relative level of welfare, comfort and development along with preservation of human identity and munificence has had a long history. This subject has newly (recent years) been introduced as development. Development has been defined from different perspectives. Development is a process in which the unpleasant society changes into a pleasant society and it contains all the institution of the society (Monfaredian-Sarvestani, 2007). Development isn't just an economical phenomenon and it is a multidimensional issue and it can be said that constant development of the whole society and social system toward a better and more human like life can be realized by using the existent resources (Tudaro, 1990). Among the goals of new definition of development, some of them can be mentioned as follow: increasing people's self-confidence, decreasing poverty and joblessness, coordinating wealth and income, enhancing the social welfare, providing people's corporation and so on. Distinguishing different levels for development is also an approach to measure the development of the districts which indicate the spatial, economic, social and cultural differences of districts and it can be used in planning the spatial development which should pay attention to needful and not well developed districts and decrease the imbalance (Momeni, 2010).

\section{Theoretical Basics}

Nowadays in order to improve the economic infrastructure and releasing from dependence and eliminating the existing imbalances, the developing countries need planning, recognizing their countries' facilities and resources. 
Certainly, recognizing the situation and regions is among the most important factors in reaching the development in planning the growth and development. Accessing the facilities and zoning properly are the elements which the county managers have put them in top of their agenda in order to reach the purposes like the beauty and welfare of the county (Monfaredian-Sarvestani, 2007). Regional development theories are raised after the World War II by some pioneers like Walter Izard and Gunnar Myrdal. Their purpose has been establishing social justice, optimum distribution of resources, facilities, welfare and wealth. The regional development theories can be classified into two groups. Regarding the social and economic activities, the first group can be divided to functional sections and also regarding the sectional planning it can be divided into regional development. The second group contains those theories which are based on the priority of human spatial territory and their activities and integration in the environment over the spatial planning for the regional development (Monfaredian-Sarvestani, 2007).

Perroux proposed the strategic theory of 'Growth Pole' for the development of less developed counties (Hosseinzadeh-Dalir, 2001). Defining development as a disintegrated and dense process of spatial system innovations, he has divided it as center-periphery (Friedman, 1979). Examining the concept of social justice, D. Harvey necessarily synonymizes the fair distribution in the scale of land and region with fair distribution in the level of regions and regards the allocation of resources to a specific region as unfair.

The hierarchical theory of settlement is also proposed by Christaller and Loush. Christaller states the dependence between the counties and villages and also the hierarchical design of functions in theory of location of services (Hosseinzadeh-Dalir, 2001). Mysra and Fabogovich (2007) also believe that the purpose of all the development processes is the human welfare and the district development is not an exception. In order for the comprehension of spatial construction of the region and prediction of changes in the process of development process, John Friedman has also proposed the center- periphery theory and has determined the center as the source of development which expands to the periphery by the increase of development in the center (Clark, 2000). The relation that exists between these two is a colonial relation (PapeliYazdi \& Sanajerdi, 2003). This theory has deepened the gap between wealth and poverty and lowered the process of development by focusing on the industries and facilities in big counties and the dominant district counties in the Third World countries (Shokouee, 1998). In this regard, looking carefully at the district issues, the district planning is going to organize the living centers in the regions and also aims to provide the most important living situations and appropriate relation among the living centers (Qanbari Haft Cheshme et al., 2005).

Like other countries, in Iran, the development of the counties of a province may not be properly processed because of disintegrated spatial distribution of resources and also different economic, social and natural elements of the regions (Mollaee, 2008). Therefore, since the general purpose of development is the multidimensional growth of the societies (Asayesh, 1996), it is necessary to compare the indices in the counties of a province and in different economic, social and cultural parts in the beginning and end of every plan to prepare a regional development. Doing this, the planners would be able to properly allocate the budgets and move toward the social justice which is among the purposes of the plan to eliminate the differences between the counties' development (Amin Bidokht, 2006) and this is our purpose of doing this research.

In the current research, the development level of counties of Qazvin province is determined by using 48 development indices (in different infrastructural parts, educational- cultural and social, agricultural, industrial and hygienic). The data have been gathered by statistical annual of year 2011 and have been analyzed by factor and also cluster analysis approach. The data are processed by SPSS software and then the counties have been ranked. The results of the research can scientifically guide the regional planners to practically evaluate the effects of the plans and development programs to revise them or improve the new programs and make the investments, monetary and human resources more purposeful.

Various researches have been done in specifying the regional development and studying the districts inequalities out and inside of country. Using the factor analysis and cluster analysis has recently been common in organizing programs (Sarrafi, 1998). Employing the factor analysis and taxonomy approach, Ashtari did a research to show the development level of counties in Azerbayjan Qarbi province and found out that the relation between the improvement of development levels is $224 \%, 166 \%$ and $75 \%$ (Ashtari, 1994).

In a paper entitled factor analysis and mixing the indices in determining the effective impacts on human development of districts of Iran, Musavi and Hekmat Nia decreased 38 statistical indices to 6 factors by using statistical analysis and then divided the counties of Iran to developed and deprived categories.

The usage of factor analysis in defining the spatial development pattern and non- development of countyregions in Iran has been written by Ebrahim Zade and Eskandari Sani, in which 32 counties are ranked as 
developed, 76 counties as higher than semi developed, 126 counties less than semi developed and 106 counties are ranked as deprived (Ebrahimzadeh \& Eskandari, 2010). In 2009, using the factor and cluster analysis approach, Nastaran and Ganjali Zade examined the degree of development of counties in Azerbayjan Sharqi province (Ganjali Zade et al., 2009). Applying the factor and cluster analysis in evaluating the spatial regions of villages in Esfahan in 2009 Taghvaee and Shafiee classified the villages of Esfahan Province by using 48 indices, changing them into 4 factors and determining the varianceof $76 \%$ (Taghvaee \& Shafiee, 2009). In a paper entitled Evaluating the Development of the Villages of Kavar District in Shiraz, Maghsoud Bayat employed the cluster analysis approach and explained the differences and inequalities of development of this district (Bayat, 2009). The changes of employment background (case study: Alvand- Qazvin) has been done by Marsusi et al in 2010. They have studied the basic changes of Alvand in four decays and found a significant correlation between the size of the county and industrial and service sections.

Considering the international papers, using the statistical techniques like multivariable factor analysis and cluster analysis Joe et al have done the ranking of Belgium by 23 indices, they also studied the development levels of each index in this country (Joe et al., 2001). Furthermore, Bahatia and Rai have used 23 indices and applied the factor analysis and numerical taxonomy in order to specify the development level of 380 blocks in 32 regions of India in 2004 (Bahatia \& Rai, 2004). Martin and Pendall used the factor analysis approach and evaluated the infrastructural indices of 50 metropolitans in the whole parts of USA (Pendall, Martin, \& Puentes, 2009).

In a paper entitled The Economic District development Using Factor Analysis in Japan, Kozoyamura studied the development level between 1955-1960 by 7 indices of urbanization, industries, factory industries, economic exchanges, Mother industries, communication and public transportation and service and determined the development level in Japan. Ignatius and Madu (2007) examined the essential factors of village development in 35 villages in south west region of Nigeria in 2007. They changed the regarded indices by factor analysis to 4 factors with the variance of $71.3 \%$. They showed that the village development is multidimensional and the infrastructural factor is the most important factor. They finally concluded that most of the villages of this region are deprived (Ignatius \& Madu, 2007). So many other related researches have also been done in Iran and also the whole world which cannot be mentioned here because of the shortage of space in this paper.

\section{Scope of Research}

Qazvin province with an area of 15,568 square kilometers is about one percent of the total area of the country and is currently considered the twenty-sixth province (Shourmij et al., 2012). This province is located between 48 degrees and 44 minutes to 50 degrees and 53 minutes from east length of the Greenwich meridian and 35 degrees and 37 minutes to 36 degrees and 49 minutes from north latitude of the equator.

Table 1. General features of political subdivisions and the population features of Qazvin Province in 2011

\begin{tabular}{cccccccc}
\hline County & $\begin{array}{c}\text { Date of } \\
\text { Establishment }\end{array}$ & $\begin{array}{c}\text { Area (Square } \\
\text { Kilometers) }\end{array}$ & Population & District & Town & $\begin{array}{c}\text { Rural } \\
\text { District }\end{array}$ & $\begin{array}{c}\text { Number of } \\
\text { Villages }\end{array}$ \\
\hline Abyek & 2001 & 1318 & 1201565 & 2 & 2 & 5 & 112 \\
Alborz & 2002 & 416 & 93844 & 2 & 4 & 4 & 35 \\
Bouein Zahra & 1996 & 5673 & 164723 & 6 & 7 & 14 & 303 \\
Takestan & 1980 & 2591 & 172949 & 4 & 5 & 9 & 149 \\
Qazvin & 1937 & 5570 & 566773 & 5 & 7 & 14 & 595 \\
\hline
\end{tabular}

Source: the Statistical Annual of Qazvin Province, 2011

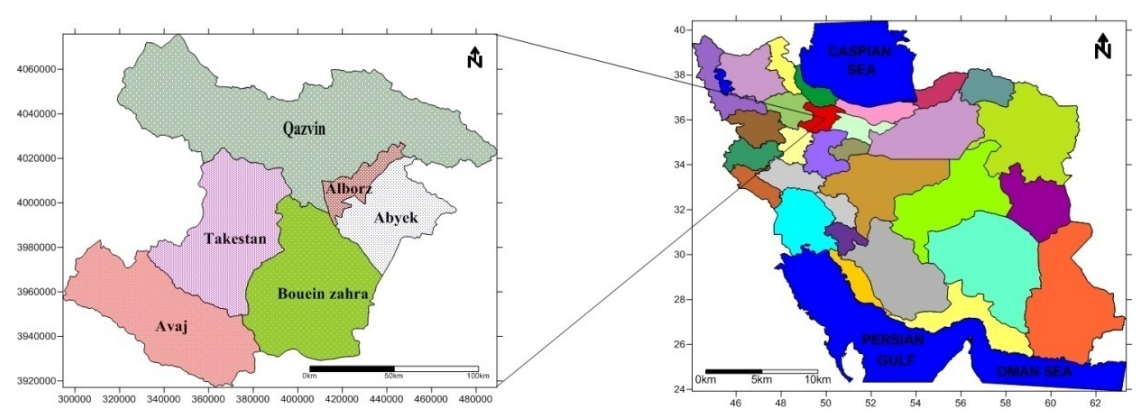

Map 1. Geographical Position of the Under Study Region 
In terms of the relative position, it is northerly next to Mazandaran and Gilan, southerly next to Markazi and Hamadan, and from the west and east part it adjoins Zanjan and Alborz Provinces respectively .Various factors like being close to Caspian Sea, neighboring with populated provinces and having the Western Alborz Mountain in the northern margin of the province, great communication situation have provided so many environmental potentials in Qazvin. According to the last country subdivision at the end of 2011, Qazvin has 5 counties called Qazvin, Takestan, Bouein Zahra, Abyek and Alborz and it has 25 towns, 19 districts, 46 rural districts and 1150 villages (Statistical annals, 2011).

\section{Methodology}

The current paper which is a descriptive-analytic paper is practically aimed to rank the counties of Qazvin province to their proper level of development. The first step is the extraction of existing variables from the statistical annual of Qazvin province in 2011. After doing this, 48 different indices in the hygienic, cultural, educational- social, agricultural- animal husbandry, industrial and infrastructural aspects have been collected through capitation and different proportions and been entered in Excel and SPSS. The above mentioned indices were reduced to 4 superior factors by $\mathrm{R}$ factor analysis approach. The Eigen value, percent of variance, cumulative percent of value and correlation coefficient have been computed for each factor and in order to avoid the dispersion of the factors, the ranking of the counties has been done according to integrated factors and then the ranking of equal regions has been done to codify the plans. The ranking has been done using the primary indices by the cluster analysis approach to form the proximity matrix to determine the distance from a county to the next. Then, using the hierarchical, forming the agglomeration matrix and average linkage, the ranking of counties has been done in 3 equal levels and the dendogram has been drawn for them.

\subsection{Index Selection}

The selection of indices is the most important step in the district development studies and in fact it is the statistical statement of existing phenomenon in a district (Kalantari, 2001). To do this, some integrated indices like economic, social and cultural, educational, hygienic, industrial, agricultural and animal husbandry have been used. Obviously, since the results gained from integrated indices are more valid, 48 indices in hygienic, culturaleducational, social, infrastructural - framework, agricultural- animal husbandry and industrial aspects have been employed in the current paper.

\subsection{Factor Analysis}

The factor analysis has been created as a statistical approach for the reduction of variables (Alijani, 2002). Meanwhile, the findings are summarized in ways which are significantly correlated (Talebi \& Zangi Abadi, 2001). The advantage of this approach is that not only it reduces the number of variables, but also it constants the primary value of variance (Variety or diffraction) in the main data (Alijani, 2002). In factor analysis, if the aim is summarizing the number of indices significant factors, the $\mathrm{R}$ factor analysis should be used, this type is mostly used in geographical studies for the ranking of regions, counties and rural districts.

\subsection{The Steps of Doing Factor Analysis in the Study}

\subsubsection{The Formation of Data Matrix}

The data matrix is a matrix whose columns are the indices and the rows are the regions. Therefore if we have $\mathrm{m}$ indices and $n$ counties, the matrix will be $m * n$. In the current research, regarding the fact that there are 5 counties in Qazvin province and 48 indices, there will be a $5 \times 48$. The employed indices in the paper are reported in Table 2.

\subsubsection{The Computation of Correlation Matrix}

The correlation matrix is used in the next steps and also the internal relation of indices. The closer is the value of the internal correlation among the variables; the less will be the number of the created factors (Darunkamp,1991). The correlation among the $\mathrm{m}$ indices can be written like $\mathrm{m} * \mathrm{~m}$ matrix. So, the matrix will be $48 \times 48$ matrix in the current research.

\subsubsection{The Extraction of Factors}

The extraction of factors is done by forming the correlation matrix among the variables. Using the factor matrix, the common factors and the relative importance of each index will be specified, then the special vectors which are the loading value that corresponds with each index for the related factor and is called factor loading is specified. In order to make a proper and logical relationship between the indices and the factors, those indices are used whose correlation coefficient is above 0.5 (Anderson, 1985). The achieved results for Qazvin province has been the reduction of 48 to 4 factors which totally covers $100 \%$ of the variance which shows the satisfaction 
of the factor analysis and the under studied indices. The special value and the percentage of the variance of each factor have been shown in Table 3.

Table 2. Employed indices in determining the development level of counties in Qazvin Province

\begin{tabular}{|c|c|c|c|}
\hline Main Indices & Row & Sub-index & Index Code \\
\hline \multirow{9}{*}{ Hygienic } & 1 & The number of medical centers per 10,000 people & $\mathrm{X} 1$ \\
\hline & 2 & The number of bed per 10,000 people & $\mathrm{X} 2$ \\
\hline & 3 & The number of laboratory per 10,000 people & $\mathrm{X} 3$ \\
\hline & 4 & The number of pharmacy per 10,000 people & $\mathrm{X} 4$ \\
\hline & 5 & The number of doctors per 10,000 people & $\mathrm{X} 5$ \\
\hline & 6 & The number of dentists per 10,000 people & X6 \\
\hline & 7 & The number of paramedic per 10,000 people & $\mathrm{X} 7$ \\
\hline & 8 & The number of radiography centers per 10,000 people & $\mathrm{X} 8$ \\
\hline & 9 & The proportion of literate people to the whole population & $\mathrm{X} 9$ \\
\hline \multirow{7}{*}{$\begin{array}{c}\text { Educational- } \\
\text { cultural }\end{array}$} & 10 & The proportion of number of classes to the whole population & $\mathrm{X} 10$ \\
\hline & 11 & The number of schools per 10,000 people & $\mathrm{X} 11$ \\
\hline & 12 & The proportion of number of students to the whole population & $\mathrm{X} 12$ \\
\hline & 13 & The proportion of educative chairs to the whole population & $\mathrm{X} 13$ \\
\hline & 14 & The proportion of book exhibition visitors to the whole population & $\mathrm{X} 14$ \\
\hline & 15 & The number of libraries per 10,000 people & $\mathrm{X} 15$ \\
\hline & 16 & The number of existing books to the whole population & $\mathrm{X} 16$ \\
\hline \multirow{11}{*}{ Infrastructural } & 17 & The number of library members to the whole population & $\mathrm{X} 17$ \\
\hline & 18 & The proportion of existing roads to the area of the county & $\mathrm{X} 18$ \\
\hline & 19 & The proportion of rural roads to the area & $\mathrm{X} 19$ \\
\hline & 20 & The proportion of landline phones to the population & $\mathrm{X} 20$ \\
\hline & 21 & The proportion of cell phones to the population & $\mathrm{X} 21$ \\
\hline & 22 & The proportion of villages with phone to the whole number of villages & $\mathrm{X} 22$ \\
\hline & 23 & The proportion of water counter of rural families to the whole population & $\mathrm{X} 23$ \\
\hline & 24 & The proportion of waste water users to the county population & $\mathrm{X} 24$ \\
\hline & 25 & The proportion of electric county customers to the whole population & $\mathrm{X} 25$ \\
\hline & 26 & The number of rural families who own electric county to the whole number of rural families & $\mathrm{X} 26$ \\
\hline & 27 & The number of home gas users to the population & $\mathrm{X} 27$ \\
\hline \multirow{12}{*}{$\begin{array}{l}\text { Agricultural- } \\
\text { animal } \\
\text { husbandry }\end{array}$} & 28 & The proportion of grain infields area to the whole grain infields of the province & $\mathrm{X} 28$ \\
\hline & 29 & The proportion of cereal infields to the whole cereal infields of the province & $\mathrm{X} 29$ \\
\hline & 30 & The proportion of number of eggs to the eggs in the whole province & $\mathrm{X} 30$ \\
\hline & 31 & The proportion of number of sheep and cows to the whole province & $\mathrm{X} 31$ \\
\hline & 32 & The proportion of number of sheep to the whole province & $\mathrm{X} 32$ \\
\hline & 33 & The proportion of the production of herbal medicine to the whole province & $\mathrm{X} 33$ \\
\hline & 34 & The proportion of Horticultural products to the whole province & X34 \\
\hline & 35 & The proportion of cold water fish production to the production of whole province & $\mathrm{X} 35$ \\
\hline & 36 & The proportion of warm water fish production to the production of whole province & $\mathrm{X} 36$ \\
\hline & 37 & The proportion of number of broilers hens to the whole province & $\mathrm{X} 37$ \\
\hline & 38 & The proportion of number of layer hen to the whole province & $\mathrm{X} 38$ \\
\hline & 39 & The amount of production of Irrigated and dry products to the whole province & X39 \\
\hline \multirow{6}{*}{ Industrial } & 40 & The proportion of active industrial plants to the active industrial plants of the province & $\mathrm{X} 40$ \\
\hline & 41 & The proportion of investment in the active industrial units to the whole province & $\mathrm{X} 41$ \\
\hline & 42 & The proportion of employment capacounty in the running industrial plans in the province & $\mathrm{X} 42$ \\
\hline & 43 & The proportion of fixed investment in the running industrial plans to the whole province & $\mathrm{X} 43$ \\
\hline & 44 & The proportion of employment in the running industrial plans to the province & $\mathrm{X} 44$ \\
\hline & 45 & The proportion of operating mines to the whole province & $\mathrm{X} 45$ \\
\hline \multirow{3}{*}{ Social } & 46 & The reverse proportion of the families who supported by the relief committee & $\mathrm{X} 46$ \\
\hline & 47 & The proportion of families who use the social insurance to the population & $\mathrm{X} 47$ \\
\hline & 48 & The proportion of families who use the Health Care insurance & $\mathrm{X} 48$ \\
\hline
\end{tabular}

Resource: Statistical computation by the researchers 
Table 3. Extraction of final factors of data analysis

\begin{tabular}{cccc}
\hline Factors & Special Value & The percentage of variance & The total percentage of variance \\
\hline 1 & 18.946 & 39.472 & 39.472 \\
2 & 17.190 & 35.8112 & 74.283 \\
3 & 6.730 & 14.020 & 89.304 \\
4 & 5.134 & 10.696 & 100 \\
\hline
\end{tabular}

Source: Statistical Computation by the Researchers

\subsubsection{Factor Rotation}

The changing of factor loading variables is not easy without rotation; therefore, the factors are rotated to be more interpretable (Momeni, 2010). In matrix rotation, the factors alternatively are rotated around a fixed point to include the indices. This method is called rotated factor matrix (Afshani et al., 2004). The varimax and quarimax approaches can be used in factors rotation. The results of factors rotation gained by varimax approach are represented in Table 4.

Table 4. Rotated factors

\begin{tabular}{cccc}
\hline Factors & Special Value & The percentage of variance & The total percentage of variance \\
\hline 1 & 17.072 & 35.567 & 35.567 \\
2 & 15.944 & 33.217 & 68.784 \\
3 & 8.500 & 17.707 & 86.491 \\
4 & 6.484 & 13.509 & 100 \\
\hline
\end{tabular}

Source: Statistical Computations by the researchers

\subsubsection{Naming the factors}

Regarding the nature and under study indices of each factor, that factor will be named (Mutalk, 1992). Considering the correlation which is among the indices, proper names can be selected for them. The factors have been named according to their effectiveness as the following:

First Factor: Hygienic- infrastructural

The special value of this factor is 17.07 which can explain the $35.56 \%$ of the variance. 20 indices have been loaded in this factor. With regard to table no 5 and the content of above mentioned factors, this factor can be named as hygienic- infrastructural factors. This factor has been the most effective factor among the factors of four of which Qazvin has had the biggest value of 1.78 and stands in the first place and Alborz has the lowest value of -0.552 and stands in the lowest place.

Table 5. Loaded indices in the first factor

\begin{tabular}{clc}
\hline Row & Index & $\begin{array}{c}\text { Correlation } \\
\text { coefficient }\end{array}$ \\
\hline 1 & The number of beds per 10,000 people & 0.988 \\
2 & The number of pharmacies per 10,000 people & 0.946 \\
3 & The number of doctors per 10,000 people & 0.809 \\
4 & The number of dentists per 10,000 people & 0.962 \\
5 & The number of radiography centers per 10,000 people & 0.801 \\
6 & The number of paramedic per 10,000 people & 0.922 \\
7 & The proportion of literate people to the whole population & 0.530 \\
8 & The proportion of students to the whole population & 0.682 \\
9 & The proportion of educative chairs to the whole population & 0.849 \\
10 & The proportion of book exhibition visitors to the whole population & 0.657 \\
11 & The proportion of rural roads to the area & 0.696 \\
12 & The proportion of number of home phones to the population & 0.629 \\
13 & The proportion of cell phones to the whole population & 0.996 \\
14 & The proportion of electric county customers to the whole population & 0.879 \\
15 & The proportion of cold water fish production to the production of the province & 0.980 \\
16 & The proportion of warm water fish production to the production of the province & 1 \\
17 & The proportion of active industrial plants to the active industrial plants of the province & 0.940 \\
18 & The proportion of investment in the active industrial plants to the whole province \\
19 & The proportion of employment capacounty in the running industrial plans in the province & 0.571 \\
20 & The proportion of operating mines to the whole population & 0.713 \\
\hline
\end{tabular}

Source: Researchers' computations 
Second Factor: Agricultural- animal husbandry

The special value of this factor is 15.944 which can explain $33.217 \%$ of the variance. In this factor, 22 indices have been loaded which has been named agricultural- animal husbandry factor because of the agricultural indices. Bouein Zahra has the best rate of 1.64 and Alborz has the least rate which is 1.056 and is not very satisfactory.

Table 6. Loaded indices in the second factor

\begin{tabular}{clc}
\hline Row & Indices & Correlation \\
Coefficient
\end{tabular}

Source: Researchers' Computations

Third Factor: Industrial- educational

The industrial- educational factor has been the third effective factor in the development of the counties of Qazvin. The special value of this factor is 8.5 which explain the $17.7 \%$ of the variance. 10 indices have been loaded in this factor. Takestan has the highest rate of 1.728 and Abyek is benefitted from the lowest indices of this factor.

Table 7. Loaded indices in the third factor

\begin{tabular}{clc}
\hline Row & Indices & $\begin{array}{c}\text { Correlation } \\
\text { coefficient }\end{array}$ \\
\hline 1 & The number of laboratory per 10,000 people & 0.648 \\
2 & The number of libraries per 10,000 people & 0.628 \\
3 & The proportion of books to the whole province & 0.810 \\
4 & The proportion of library members to the whole population & 0.948 \\
5 & The proportion of landline phones to the whole population & 0.621 \\
6 & The proportion of cereal infields to the whole cereal infields of the province & 0.981 \\
7 & The proportion of herbal products to the whole province & 0.979 \\
8 & The proportion of broiler hens to the whole province & 0.725 \\
9 & The proportion of fixed investment of the running industrial plans to the whole province & 0.933 \\
10 & The reverse number of families who use the relief committee help & 0.549 \\
\hline
\end{tabular}

Source: Researchers' Computations

\section{The Fourth factor: Educational- infrastructural}

The special value of this factor is 16.48 which explain $13.5 \%$ of the variance. 11 loaded indices have been represented in Table 8 . The factor has been named as educational- infrastructural because of the indices . Having the highest rate of 1.465, Abyek has the best situation and Alborz has the lowest rate of -1.26. 
Table 8. Loaded Indices in the fourth factor

\begin{tabular}{clc}
\hline Row & Indices & $\begin{array}{c}\text { Correlation } \\
\text { Coefficient }\end{array}$ \\
\hline 1 & The number of laboratories per 10,000 people & 0.502 \\
2 & The proportion of literate people to the whole population & 0.704 \\
3 & The proportion of book exhibition visitors to the population & 0.678 \\
4 & The proportion of villages with phones to the whole number of villages & 0.747 \\
5 & The proportion of families who use electric county to the whole number of rural families & 0.867 \\
6 & The proportion of waste water tributary to the urban population & 0.578 \\
7 & the proportion of gas users to the whole population & 0.554 \\
8 & The proportion of layer hens to the layer hens of the province & 0.832 \\
9 & The proportion of investment in the running industrial plants to the whole province & 0.816 \\
10 & The proportion of employment capacounty in the active industrial plants to the whole province & 0.563 \\
11 & The proportion of employment capacounty in the running industrial plans & \\
\hline
\end{tabular}

Source: Researchers' Computations

The total value of the variance of the four factors is $100 \%$ of which $35 \%$ is for the first factor and $33 \%$ is for the second factor which shows the importance degree of two factors of hygienic- infrastructural and agriculturalanimal husbandry.

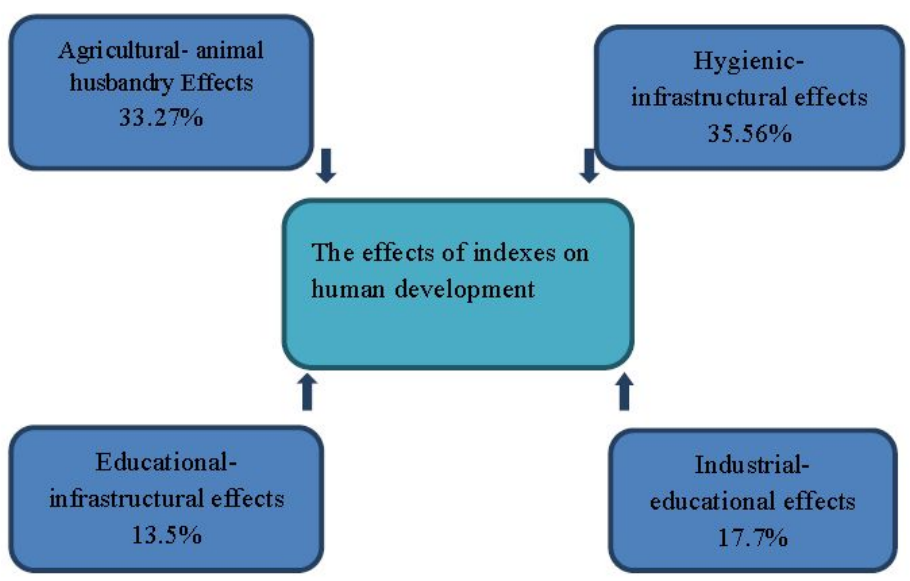

Figure 1. Analytic model of positive factors of selected indices of districts development of Qazvin Province along with the percentage of each factor (Source: Researchers' Computations)

\section{Ranking of the Counties}

In the current research, the ranking has been done for 5 counties of Qazvin Province by using the integrated index achieved by the rates of 4 factors whose results have been shown in Table 9 and Map 2. According to the findings, Qazvin has the highest rate of 1.57 and is considered as the most developed county, while Alborz has the lowest rate of -3.3 and is regarded as the most deprived county.

Table 9. Factor rate of each county of Qazvin Province (2011)

\begin{tabular}{ccccccccc}
\hline \multirow{2}{*}{ Row } & \multirow{2}{*}{ County } & \multicolumn{4}{c}{ Rate of Factors } & \multirow{2}{*}{ Integrated index } & \multirow{2}{*}{ Rank } \\
\cline { 3 - 6 } & & First & Second & Third & Fourth & & -0.24 & 4 \\
2 & Abyek & 1.47 & -0.80 & -0.40 & -0.51 & & -3.31 & 5 \\
3 & Alborz & -1.26 & -0.44 & -1.06 & -0.55 & & 0.44 & 3 \\
4 & Bouein Zahra & -0.45 & -0.42 & 1.64 & -0.34 & & 1.54 & 2 \\
5 & Takestan & 0.25 & 1.73 & -0.05 & -0.39 & & 1.57 & 1 \\
\hline
\end{tabular}

Source: Researchers' Computations 


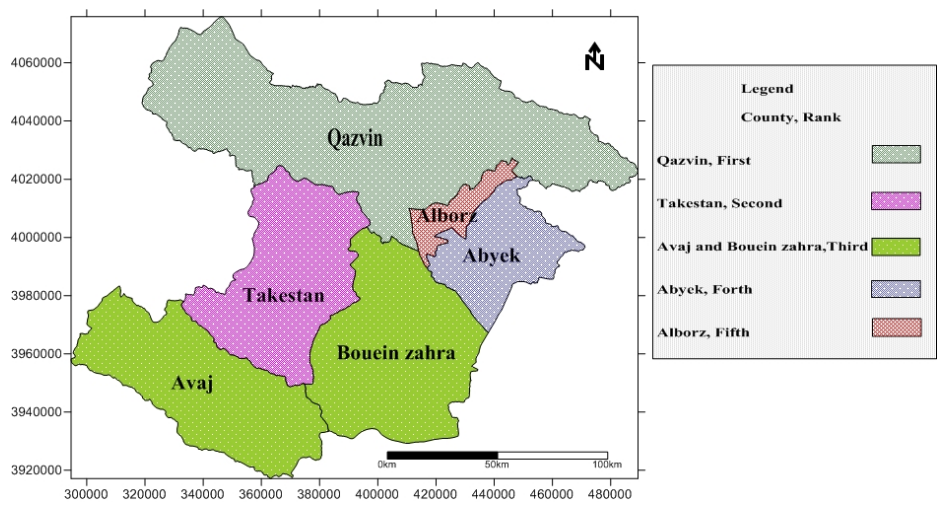

Map 2. Ranking of the counties in Qazvin based on their development

\section{Cluster Analysis}

Ranking the counties of Qazvin according to Factor analysis, the researchers then started to rank the equal places using the cluster analysis. Actually, cluster analysis is an approach for ranking the regions, counties, rural districts, etc. In this approach, the counties that are placed in a level are so much alike meanwhile they are completely different with other levels (Hekmat Nia \& Musavi, 2011).

The main aim of cluster analysis is to create levels and groups of which the internal variety and dispersion is less than the variety among the groups (Kalkstein, 1987). In this approach, an algorithm is used which start the program with each of the case or variable and then mix the clusters in such a way of which only one cluster remains (Donald, 1979). Using the average linkage and SPSS software, the researchers tried to rank the equal counties according to their development degree. The steps are explained below:

First step: Formation of Proximity Matrix

The proximity matrix is used for the ranking of the counties by cluster analysis approach (Table 10). This matrix is formed to determine the distance between the counties (Asayesh, 2000).

Table 10. Proximity matrix for the counties of Qazvin Province

\begin{tabular}{cccccc}
\hline \multirow{2}{*}{ The Counties of the Province } & \multicolumn{5}{c}{ The Square of Euclidean Distance } \\
\cline { 2 - 6 } & Abyek & Alborz & Bouein Zahra & Takestan & Qazvin \\
\hline Abyek & 0 & 0.975 & 0.969 & 0.977 & 0.082 \\
Alborz & 0.975 & 0 & 0.863 & 0.888 & 0 \\
Bouein Zahra & 0.969 & 0.863 & 0 & 1 & 0.81 \\
Takestan & 0.977 & 0.888 & 1 & 0 & 0.86 \\
Qazvin & 0.82 & 0 & 0.81 & 0.86 & 0 \\
\hline
\end{tabular}

Source: Researchers' Computations

\section{Second Step: Formation of Density Matrix}

In this approach, first, two counties which have the least distance are identified and form the first cluster. Then, the third county is added to this cluster and is integrated with two other counties and form a new cluster. The formation of second cluster depends on the fact that whether the third county is closer to the counties of the first cluster or to the other counties which are in the same cluster. This process continues until all the counties are placed in one cluster. The distance between the clusters is called the distance between the closest members (Asayesh, 2000). The clustering steps and also the integration coefficient for the counties of Qazvin Province have been represented in Table 11 .

Table 11. Density matrix and clustering steps of the counties of Qazvin Province

\begin{tabular}{cccccccc}
\hline Clustering & \multicolumn{2}{c}{ Clusters integration } & Integration & \multicolumn{2}{c}{ Primary clustering } & Repetition in the next \\
\cline { 2 - 3 } Steps & Cluster 1 & Cluster 2 & Coefficient & Cluster 1 & Cluster 2 & steps \\
\hline 1 & 3 & 4 & 1 & 0 & 0 & 3 \\
2 & 1 & 2 & 0.975 & 0 & 0 & 3 \\
3 & 1 & 3 & 0.924 & 2 & 1 & 4 \\
4 & 1 & 5 & 0.62 & 3 & 0 & 0 \\
\hline
\end{tabular}

Source: Researchers' Computations 
Third Step: Clustering the Counties

The counties of Qazvin Province have been categorized to 3 clusters according to the selected indices and the computations. The findings have been shown in Table 12.

Table 12. Clustering the under study counties

\begin{tabular}{cc}
\hline 3 clusters & Counties \\
\hline 1 & Abyek \\
1 & Alborz \\
2 & Bouein Zahra \\
2 & Takestan \\
3 & Qazvin \\
\hline
\end{tabular}

Source: Researchers' Computations

Third Cluster: Abyek and Alborz are placed in this cluster, which have a lower degree of development according to under study indices.

Second Cluster: Bouein Zahra and Takestan are determined to be put in this cluster and are considered as semideveloped counties.

First Cluster: Qazvin which is the center of the province is regarded as the most developed county in the whole province.

Fourth Step: Counties Dendogram

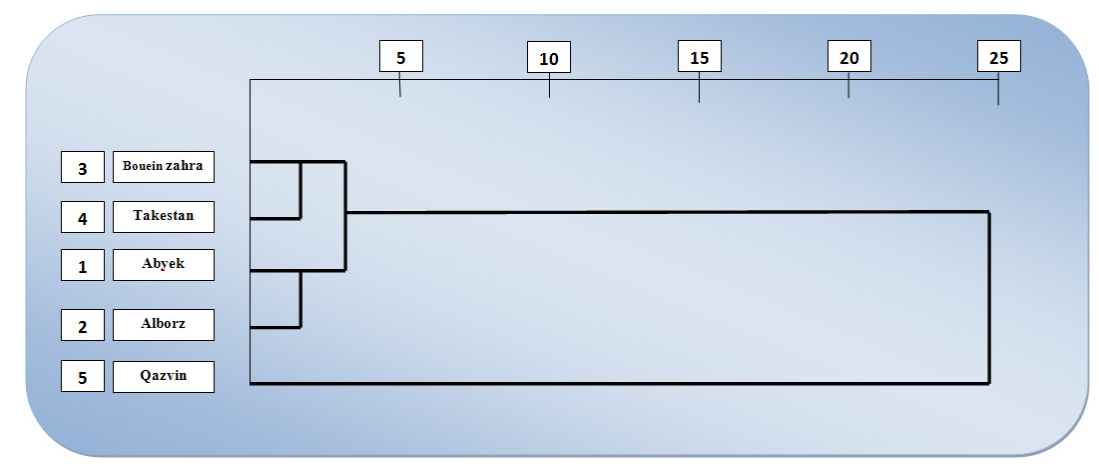

Figure 2. Clustering the counties of Qazvin (Source: Researchers' Computations)

\section{Table of Clustering the Counties}

Based on the research findings, the clustering of the counties of Qazvin Province with regard to their degree of development has been demonstrated in Table 13 and Map 3.

Table 13. Clustering of the counties of Qazvin Province with regard to their degree of development

\begin{tabular}{ll}
\hline Degree of development (based on the index) & The counties of Qazvin Province \\
\hline Developed Counties & Qazvin \\
Semi developed counties & Takestan and Bouein Zahra \\
Less developed counties & Abyek and Alborz \\
\hline
\end{tabular}

Source: Researchers' Statistical Computations

\section{Conclusions and Further Suggestions}

According to the results of this research, counties of the province are ranked as follows, with respect to development indices and based on factor analysis: Qazvin County is regarded as the most developed county followed by Takestan and Bouein Zahra counties, while Abyek and Alborz are respectively the least developed counties with respect to development indices. The results of cluster analysis which utilized the primary indices 
used in factor analysis supports these conclusions. According to the results of cluster analysis, 3 clusters can be defined in Qazvin Province where Qazvin County stands solely in the first cluster, Takestan and Bouein Zahra counties are placed in the second cluster, and Abyek and Alborz are placed in the third cluster. Considering that the first factor, the most influential indices of which were hygienic-infrastructural factors, is assigned the highest rate, it has a 2.11 difference from Bouein Zahra County, and this was also confirmed by cluster analysis results. Moreover, it can be seen that the difference in this factor is very low between other counties of the province. Hence, planning for development in hygienic and infrastructural issues in the counties of Qazvin Province with the aim of developing them and making them proportionate in terms of enjoying the development factors is highly recommended. In addition, owing to the fact that Abyek and Alborz counties were put in the fourth and fifth places of ranking on the basis of factor analysis, and in the third place on the basis of cluster analysis, they can be identified as the areas with low level of development indices. Results of the present study reveal that, in addition to planning for hygienic and infrastructural sectors, these two counties also need planning for development in agricultural and industrial sectors. Taking the privations into account as the priorities in the process of planning for development can reduce the economic and socio-cultural gap between counties of the province.

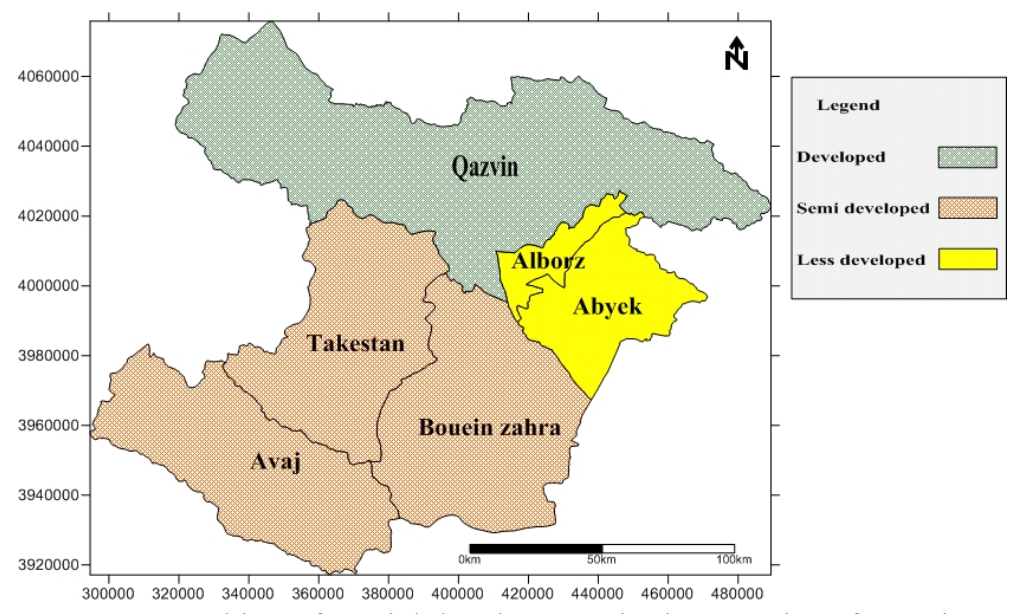

Map 3. Ranking of spatial development in the counties of Qazvin

\section{References}

Afshani, R., Hosseini, S. R., Hosseini, S. M., \& Ramshe, Z. (2004). A Review of SPSS. Bishineh Publications, Tehran, Iran.

Alijani, B. (2002). Synoptic Climatology. Publications Ministry of Foreign Affairs, Tehran, Iran.

Amin-Bidokht, A. A. (2006). Ranking the Level of Development in Cities of Semnan Province. The Growth of Geography Training, 76, 189-195.

Asayesh, H. (1996). Determination of Country's Rural Development. Unpublished Master's Thesis, Shahid-Beheshti University, Tehran, Iran.

Bahatia, V. K., \& Rai, S. C. (2004). Evaluation of Socio-economic Development in Small Area. NewDehli, India.

Bergman, E. F., \& Renwick, W. H. (2004). Introduction to Geography: People, Places, Environment (3rd ed.). Upper saddle river, New Jersey, USA.

Clark, D. (2000). Urban World/Global City. Rout Ledge, London, England.

Donald, A. (1979). Spatial Organization the Geographers View of the Word. Journal of Geography and Development, 3, 29-41.

Drowncom, B., \& King, A. (1993). Quantitative Analysis in Geomorphology, Yazd University Press, Yazd, Iran.

Ebrahimzadeh, E., \& Eskandari-Sani, M. (2010). The Application of Factor Analysis in Explanation for Spatial Pattern of Urban - Regional Development and Underdevelopment in Iran, Journal of Geography and Development, 17, 76-86

Friedman, J. (1979). A General Theory of Polarized Development. In N. N. Hassan (Ed.), Growth Centers in 
Regional Economic Development. Macmillan co, ltd.

Ganjalizadeh, B., \& Mahin, N. (2009). Analysis of Development Degree in Cities of East Azarbayjan Province Using Factor and Cluster Analysis. Journal of City Making, 12, 56-68.

Ghanbari-Haftcheshmeh, A., \& Hosseinzadeh-Dalir, K. (2005). Determination of Development Degree in Cities of East Azarbayjan Province. Journal of Geography and Regional Development, 5, 78-86.

Hekmatnia, H., \& Mousavi, M. N. (2010). Application of Model in Geography with Emphasis on Urban and Regional Planning (1st ed.). Elme-Nowin Publications, Yazd, Iran.

Hosseinzadeh- Dalir, K. (2010). Regional Planning (10th ed.). Tehran, Iran: Samt Publications.

Ignatius, A., \& M. (2007). The Underlying Factors of Rural Development Patterns in the Nsukka Region of Southeastern Nigeria. Journal of Rural and Community Development, 3, 25-36.

Inanlou, A. (2011). Study of Hierarchical System for Cities of Qazvin Province. Journal of the Growth of Geography, 6(2).

Joao, O., Manuela L., Marques, C., \& Ferreira, M. (2001). A Multivariate Methodology to Uncover Regional disparities: A Contribution to Improve European Union and Gower mental Decisions. Italy: Marcos Publications.

Kalantari, K. (2003). Processing and Analyzing Data in Social-Economical Researches Using SPSS Software. Tehran, Iran: Sharif University Press.

Kalkstien, L. S. (1987). An Evaluation of Three Clustering Procedures for Use in Synoptic Climatologically Classification, Journal of Climate Meteorology, 26(2).

Mashhadizadeh-Dehaghani, N. (1999). The Analysis of Urban Planning Features in Iran. Publications of Science and Technology University, Tehran, Iran.

Mesira, R. P., \& Mabogij, A. L. (2007). Regional Development, New Methods. Programming and Budget Organization Press, Tehran, Iran.

Molaee, M. (2008). Study of Development Degree Comparison in Agriculture Section of Iran Provinces. Journal of Agriculture Economic and Development, 63(1).

Momeni, M. (2010). Principles and Methods of Regional Planning. Publications of Islamic Azad University of Najafabad, Isfahan, Iran.

Monfaredian-Sarvestani, M. (2007). Ranking the Different Urban Regions of Shiraz Regarding Development Degree. Unpublished Master's Thesis, Isfahan University, Iran.

Papeli, M. H., \& Rajabi, S. H. (2003). Theories of the City and Surrounding. Samt Publications, Tehran, Iran.

Sarrafi, M. (1998). Foundations of Planning for Regional Development, Program and Budget (1st ed.). Tehran.

Shokouei, H. (1994). New Perspectives in Urban Geography. Samt Publications, Tehran, Iran

Shurminj, R. A. (2012). Geological Province for Qazvin. Golchin Publications, Tehran, Iran.

Taghvaei, M. (2005). Utilization of Human Development Indices for Determination of Urban Regions' Deprivation and Classification: Provinces of Country. Journal of Literature and Humanities of Chamran University of Ahwaz, 1(3).

Talebi, H., \& Zangi-Abadi, A. (2001). The Analysis and Effective Factors' Determination of Indices in Human Methodology for Major Cities of Country. Iranian Journal of Geographical Research, 3(2).

Tudaro, M. (1990). Economic Development in Third World. Publications of Higher Institution for Research in Planning and Development, Tehran, Iran.

Tuolayi, S. (1996). Introduction to Economic Geography. Teacher Training University Press, Tehran, Iran.

\section{Copyrights}

Copyright for this article is retained by the author(s), with first publication rights granted to the journal.

This is an open-access article distributed under the terms and conditions of the Creative Commons Attribution license (http://creativecommons.org/licenses/by/3.0/). 